\title{
Litsea cubeba Essential Oil Yield Harvested from Different Habitat Types on Mt. Papandayan, West Java, Indonesia
}

\author{
Ichsan Suwandhi ${ }^{1,2}$, Cecep Kusmana $^{1}$, Ani Suryani $^{3} \&$ Tatang Tiryana $^{4}$ \\ ${ }^{1}$ Departement of Silviculture, Faculty of Forestry Institut Pertanian Bogor, \\ Jl. Raya Darmaga Kampus IPB Darmaga Bogor 16680, Indonesia \\ ${ }^{2}$ School of Life Sciences and Technology, Institut Teknologi Bandung, \\ Jalan Ganesha No. 10, Bandung 40132, Indonesia \\ ${ }^{3}$ Department of Agroindustrial Technology, Faculty of Agriculture Engineering and \\ Technology IPB, Jl. Raya Darmaga Kampus IPB Darmaga Bogor 16680, Indonesia \\ ${ }^{4}$ Departement of Forest Management, Faculty of Forestry, Institut Pertanian Bogor, \\ Jl. Raya Darmaga Kampus IPB Darmaga Bogor 16680, Indonesia \\ Email: ichsan@sith.itb.ac.id
}

\begin{abstract}
The objective of this research was to determine the yield and chemical composition of Litsea cubeba essential oil harvested from different habitat types on Mount Papandayan, West Java, Indonesia. The methods used were determination of sample plots at each habitat, followed by laboratory testing. Leaf samples were taken from each plot, the oil was extracted in the laboratory using steam distillation, which was subsequently analyzed by GC-MS. The results showed that the yield of essential oil was high $(2.76-9.33 \%)$. The three dominant chemical compounds found were eucalyptol (16.97-55.78\%), $\alpha$ terpinenyl acetate (7.27-20.44\%), and sabinene (14.45-68.05\%). The results confirmed the expectation that Litsea cubeba essential oils extracted from Litsea cubeba trees growing in various habitats on Mount Papandayan would show a variety in yield and chemical composition.
\end{abstract}

Keywords: composition; essential oil; Litsea cubeba; site types; varieties.

\section{$1 \quad$ Introduction}

Litsea cubeba Lour. Persoon is a small to medium-sized tree that belongs to the Lauraceae family. Its Indonesian name is kemukus and local names are ki lemo or lemo (West Java), krangean (Central Java), and attarasa (North Sumatera). In China, it is known as may chang [1,2]. Products from the tree have multiple applications $[3,4]$. Each part of the tree has high economical value, from its wood, bark, branches, leafs, fruit, and flowers to its roots [4,5-7]. It is well known as a potential source of essential oil for industrial products such as cosmetics (aroma therapy), soap, perfume, skin cleaner, and acne medicine. Essential oil from this tree is also the source of an agent that is believed to be a carcinostatic (anti-cancer). Other applications of L. cubeba essential oil are: bioinsecticides and anti-termite agents [8,9], antimicrobe active alkaloid 
isoquinoline is used as a traditional medicine [10], antibacterial agent [11,12], and antioxidant [13]. A research in Thailand showed that essential oil from $L$. cubeba can be used as a repellent for the Aedes aegypti mosquito [13].

On Mount Papandayan, L. cubeba grows in various habitats. It is assumed that the amount and quality of the essential oil produced by L. cubeba varies depending on the substrate on which it grows. To confirm this assumption, it was necessary to conduct research to find out the contents of the essential oils taken from $L$. cubeba trees growing in different habitats.

This study was exciting to conduct because only a limited number of studies have examined the variation of essential oil from $L$. cubeba trees from different natural habitats. Several studies have been carried out in different habitats, including Mount Ciremai West Java (6), North Sumatra (15) and China (16), but these did not specifically address habitat variation and its relationship with the contents of the essential oil.

Litsea cubeba has never been cultured on a large scale. It grows mainly in natural forests, especially in highlands. The tree is threatened by human exploitation. Its culture is urgently needed for conservation of the species and for supporting the essential oil industry.

The objective of this research was to determine the production of essential oil from $L$. cubeba leafs harvested from various habitats on Mount Papandayan, West Java, Indonesia. The results were expected to provide information about the yield and contents of the essential oil taken from the different habitats.

\section{Methodology}

Two methods were used in this research: field exploration and observation, followed by laboratory testing. The determination of sample plots was conducted by purposive sampling based on: 1. stratum (based on land system map); 2. four types of terrain type; 3. altitude; 4. topography (steep/sloping/ ridge).

Leaf samples of $L$. cubeba were obtained from 15 different habitats, where every habitat was represented by one plot that contained at least one mature tree with a minimum diameter of $20 \mathrm{~cm}$. The leafs were cut from the top of the twigs along $30 \mathrm{~cm}$ in all wind directions and canopy positions (top, middle and bottom). $400 \mathrm{~g}$ of mixed leaf samples were distilled to obtain essential oil.

Extraction of the essential oil from the leaf samples was conducted by steam distillation for 2 hours or until the essential oil was fully extracted. The leaf 
samples were dried by air-drying before distillation. Each distillation needed $200 \mathrm{~g}$ of air-dried leaf samples and the distillation was carried out in duplo. The following step was to determine the contents and composition of the essential oil by GC-MS analysis (Agilent Technologies GC System (GC 7890 and 5975 C XLEI/CI MSD)) at $250^{\circ} \mathrm{C}$. The temperature of the MS detector was $28^{\circ} \mathrm{C}$ [14]. The results indicate the variability of the essential oil and its composition from the samples taken from the different habitats.

\section{$3 \quad$ Results and Discussions}

\subsection{Habitat Variation}

Based on a field survey, L. cubeba trees growing at 15 various habitats with different population sizes were selected (Table 1). All habitats were located between 1000 to $2500 \mathrm{~m}$ above sea level, ranging from flat to very steep, and were previously disturbed by illegal logging or forest fires.

Table 3 Habitats of L. cubeba on Mount Papandayan.

\begin{tabular}{|c|c|c|c|c|c|}
\hline Code & Name of location & $\begin{array}{c}\text { Altitude } \\
\text { (m above sea level) }\end{array}$ & Topography & Landscape & Land cover \\
\hline $\mathrm{H} 1$ & Sorok Teko/Tgl Puspa & $1919-1956$ & $\begin{array}{c}\text { Sloping- } \\
\text { slightly steep }\end{array}$ & Cliff & Forest fire debris \\
\hline $\mathrm{H} 2$ & Gn Walirang & $1617-2058$ & Flat-very steep & Cliff-Ridge & Bush \\
\hline $\mathrm{H} 3$ & Puntang/S. Cibeureum & 2040 & Very steep & $\begin{array}{c}\text { Cliff } \\
\text { river/ravine }\end{array}$ & Forest fire debris \\
\hline $\mathrm{H} 4$ & Bungbrun & 2169 & Flat-sloping & $\begin{array}{l}\text { Plateau at the } \\
\text { top of the hill }\end{array}$ & Forest fire debris \\
\hline H5 & $\begin{array}{l}\text { Pada Awas/Lutung- } \\
\text { Pondok Serok }\end{array}$ & 2044 & $\begin{array}{l}\text { Steep-very } \\
\text { steep }\end{array}$ & Cliff/ravine & Forest fire debris \\
\hline H6 & $\begin{array}{l}\text { Pada Awas/Tibet- } \\
\text { Lutung }\end{array}$ & 2100 & $\begin{array}{l}\text { Steep-very } \\
\text { steep }\end{array}$ & Cliff/ravine & Forest fire debris \\
\hline $\mathrm{H} 7$ & Tegal Bungbrun & 2300 & Sloping & Ridge & $\begin{array}{c}\text { Young } \\
\text { secondary forest }\end{array}$ \\
\hline $\mathrm{H} 8$ & Lembah Cibeureum & $2161-2160$ & Sloping & Plateau & $\begin{array}{c}\text { Young } \\
\text { secondary forest }\end{array}$ \\
\hline H9 & Lutung & 2040 & Steep & Cliff & $\begin{array}{c}\text { Young } \\
\text { secondary forest }\end{array}$ \\
\hline $\mathrm{H} 10$ & Tibet & 2100 & Sloping & Plateau & Gap/hiatus \\
\hline H11 & $\begin{array}{l}\text { Lereng Curug } \\
\text { Angklong }\end{array}$ & 2100 & Sloping & Plateau & Bush \\
\hline $\mathrm{H} 12$ & Batu Kasang & 1882 & Slightly steep & Ridge & $\begin{array}{c}\text { Young } \\
\text { secondary forest }\end{array}$ \\
\hline H13 & Batu Kasang 2 & 2030 & Very steep & Cliff/ravine & Gap/hiatus \\
\hline H14 & $\begin{array}{c}\text { Lembah Puntang/Supa } \\
\text { beureum }\end{array}$ & 2157 & Flat & Valley & $\begin{array}{c}\text { Young } \\
\text { secondary forest }\end{array}$ \\
\hline H15 & Tgl Panjang & 2041 & Slightly steep & Cliff & Gap/hiatus \\
\hline
\end{tabular}


Litsea cubeba generally grows within a temperature range of $16-26.3^{\circ} \mathrm{C}$ (with an average temperature of $19.24^{\circ} \mathrm{C}$ ), a humidity range of $60-95 \%$, and light intensity range of 300-85600 lux. The habitats on Mount Papandayan are colder and more humid compared to those in North Sumatra, another natural distribution area of Litsea cubeba in Indonesia apart from West and Central Java [15].

These observations show that L. cubeba can grow in open spaces with various disturbed habitats and has great potential for use as a pioneer tree [15].

\subsection{Yield of Essential Oil}

The results of the distillation process showed variation in the essential oil content of the L. cubeba leafs harvested from the 15 different habitats (Table 2). The resulting essential oils were either yellowish or colorless and had a pungent smell like citrus mixed with eucalyptus oil (Figure 1).

Table 4 Distillation results of essential oil of L. cubeba harvested from 15 habitats.

\begin{tabular}{lccc}
\hline $\begin{array}{c}\text { Sample } \\
\text { code }\end{array}$ & $\begin{array}{c}\text { Water content } \\
(\boldsymbol{\%})\end{array}$ & $\begin{array}{c}\text { Weight of essential } \\
\text { oil }\end{array}$ & $\begin{array}{c}\text { Yield } \\
(\%)\end{array}$ \\
\hline H4 & 25 & 18.65 & 9.33 \\
H13 & 71 & 18.50 & 9.25 \\
H3 & 31 & 17.85 & 8.93 \\
H8 & 36 & 16.33 & 8.16 \\
H2 & 25 & 16.13 & 8.06 \\
H5 & 40 & 15.55 & 7.77 \\
H7 & 21 & 15.04 & 7.52 \\
H1 & 9 & 14.30 & 7.15 \\
H6 & 43 & 13.88 & 6.94 \\
H9 & 27 & 13.82 & 6.91 \\
H12 & 72 & 13.62 & 6.81 \\
H11 & 11.08 & 5.54 \\
H15 & 56 & 10.24 & 5.12 \\
H10 & 57 & 9.84 & 4.92 \\
H14 & 60 & 4.27 & 4.27 \\
\hline
\end{tabular}

Table 2 shows that the yield of essential oil ranged from 2.76 to $9.33 \%$. The maximum yield in this research was higher than the extraction result of similar leafs originating from Mount Ciremai (5.4\%) [6] and China (4.56\%) [16]. 
Among all the locations, the leafs collected from locations $\mathrm{H} 4$ and $\mathrm{H} 13$ had the highest yield, followed by locations H3, H2, and H8. Further analysis showed that the essential oil yield was not affected by altitude, topography, or landscape factors but only by land cover conditions.

The resuls showed that burnt bush and forest fire debris land cover types tended to have a higher yield compared to other land cover types. This is probably due to the different level of environmental stress received by L. cubeba. Habitat stress, such as limited nutrition in the soil, can increase the production of flavanoid as secondary metabolite [17]. This implies an increase of the chemical compounds in the plant. Further research on soil characteristics is needed to explain this phenomenon.

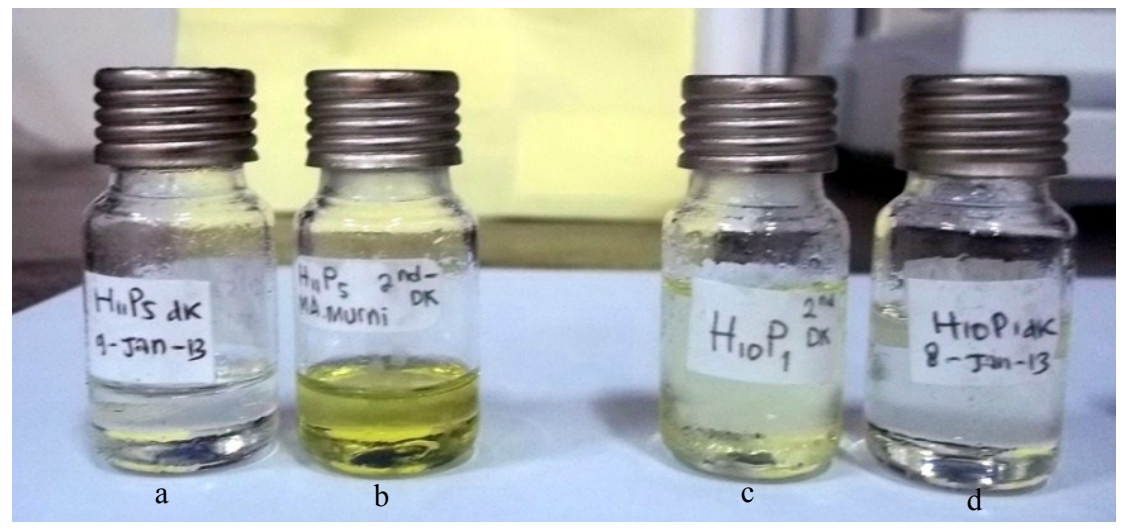

Figure 1 Color variations of L. cubeba essential oils originating from Mt. Papandayan-(a) and (d): examples of colorless essential oil; (b) and (c): examples with a yellowish color.

\subsection{Chemical Composition of Essential Oil}

GC-MS analysis showed that the chemical composition of the essential oil extracted from L. cubeba leafs from different habitats was similar, but was different in abundance of each chemical compound (Table 3).

Overall, 16 chemical substances were identified in the leaf extracts, with 8 chemical substance compounds found in all leaf samples, i.e. $\alpha$-pinene, (-)sabinene, 2- $\beta$-pinene, $\beta$-myrcene, D-limonene, eucalyptol and $\alpha$-terpinenyl acetate. There were specific chemical compounds that were found only in a specific habitat, i.e. linalool found only in the leaf samples from locations H1 and $\mathrm{H} 15$, and $\alpha$ terpineol found only in the leaf sample from location H12. 


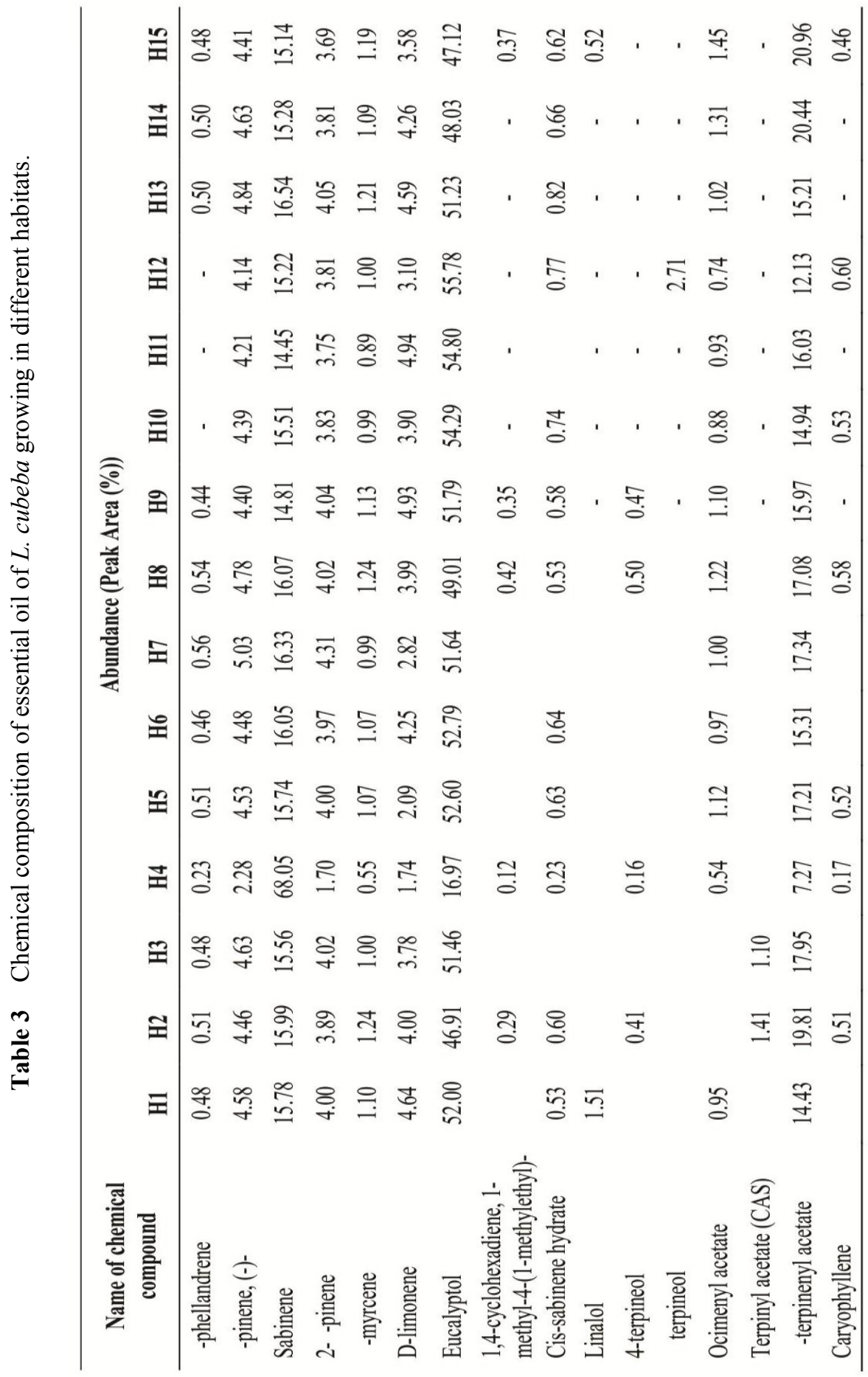


This research found three dominant chemicals in the extracted oil, i.e. eucalyptol (16.97-55.78\%), $\alpha$-terpinenyl acetate (7.27-20.44\%), and sabinene (14.45-68.05\%).

These dominant chemical compounds are different from those found through research conducted in other areas. For example, the abundance of dominant chemical compounds of the L. cubeba essential oil from: (i) Cikole West Java sineol (56.61\%) and citronellol (12.26\%) [4]; (ii) Mount Ciremai West Java sineol (56.61\%), $\beta$-pinen (14.54\%), and citronellol (12.28\%) [7]; (iii) Thailand - sabinene (42.69\%), 1.8 cineole (18.32\%), and $\beta$-pinene (6.15\%) [18]; (iv) China - monoterpenes (94.4-98.4\%), represented mainly by neral and geranial (78.7-87.4\%) [16]; (v) Zhao [19] showed that the dominant chemical compounds were citral, eucalyptol, citronellol, 6-octenal, 3,7-dimethyl-2,6 octadien-1-ol (geraniol alcohol), and so on. Wang \& Liu [12] discovered that the dominant chemical compounds were citral B (neral), $\beta$-phellandrene, and $\beta$ terpinene.

This research showed that the variety in chemical composition of the investigated samples of essential oil of $L$. cubeba was quite high. This condition is presumed to be affected by factors in the different habitats. Therefore, further research is needed to understand the ecological preference and its relation to the chemical composition of $L$. cubeba, which in turn may support the culture of $L$. cubeba.

\section{Conclusions}

Litsea cubeba has a tendency to grow well in open spaces with various land covers that have been disturbed. The yield variation of the essential oil produced by $L$. cubeba in different habitats tends to be high. The highest yield of essential oil was obtained from locations H4 (a burnt area): 9.33\% and H13 (an ex-encroachment area): 9.25\%, while the lowest yield was found in a dead forest: $4.27 \%$.

In general, it can be concluded that there is a tendency that burnt areas and exencroachment areas produce the highest yield of essential oil. Higher environmental stress results in a higher yield of essential oil. The three dominant chemical compounds found were, i.e. eucalyptol (16.97-55.7\%), terpinenyl acetate (7.2-20.44\%), and sabine (14.45-68.05\%).

Further research is needed to learn more about the ecological preference and its relation to the chemical compounds of essential oil from L. Cubeba. 


\section{Acknowledgements}

We would like to express our sincere thanks to the Indonesian Ministry of Education and Culture for financially supporting this research. We also express our gratitude to the Indonesian Ministry of Forestry for providing the research field on Mount Papandayan Nature Reserve, Faculty of Forestry IPB, Faculty of Agriculture Technology IPB, School of Life Sciences \& Technology ITB, and Integrated Laboratory of Bandung Polytechnique of Health for the laboratory equipment and analysis.

\section{References}

[1] Heyne, K., The Usefull Plants in Indonesia $2^{\text {nd }}$ Book, Yayasan Sarana Wanajaya, 1987. (Text in Indonesian)

[2] Steenis, V.C.G.G.J., The Mountain Flora of Java, Center of Biology Research, Indonesian Institute of Science (LIPI), Bogor, 2006. (Text in Indonesian)

[3] Herawati, T., Hajib, N. \& Sutigno, P., Litsea cubeba as Multipurpose Plant, Indonesian Ministry of Forestry, Jakarta, 2005. (Text in Indonesian)

[4] Heryati, Y., Mindawati, N. \& Kosasih, A.S., Development Prospects of Litsea cubeba L. Persoon in Indonesia, Jurnal Tekno Hutan Tanaman, 2(1), pp 9-17, 2009. (Text in Indonesian)

[5] Ho, C.L, Jie-Pinge, O, Liu, Y.C., Hung, C.P., Tsai, M.C., Liao, P.C., Wang, E.I., Chen, Y.L. \& Su, Y.C., Compositions and In Vitro Anticancer Activities of the Leaf and Fruit Oils of Litsea cubeba from Taiwan, 5(4), pp. 617-20, 2010.

[6] Zulnely, Kulsum, U. \& Junaedi, A., Physico-chemical Properties of Essential Oil of Litsea cubeba (Kilemo) Originated from Kuningan, West Java, Jurnal Penelitian Hasil Hutan, 2(3), 2003. (Text in Indonesian)

[7] Sylviani \& Elvida, Y.S., Study of Potential, Distribution and Feasibility of Litsea Cultivation, Jurnal Penelitian Sosial Dan Ekonomi Kehutanan, 7(1), pp. 73-91, 2010. (Text in Indonesian)

[8] Jiang, Z., Akhtar, Y., Bradbury, R., Zhang, X. \& Isman M.B., Comparative Toxicity of Essential Oils of Litsea Pungens and Litsea Cubeba and Blends of Their Major Constituents against the Cabbage Looper, Trichoplusia ni., J Agric Food Chem., 57(11), pp. 4833-7, 2009.

[9] Seo, S.M., Kim, J., Lee, S.G., Shin, C.H., Shin, S.C. \& Park, I.K., Fumigant Antitermitic Activity of Plant Essential Oils and Components from Ajowan (Trachyspermum ammi), Allspice (Pimenta dioica), Caraway (Carum carvi), Dill (Anethum graveolens), Geranium (Pelargonium graveolens), and Litsea (Litsea cubeba) Oils Against 
Japanese Termite (Reticulitermes speratus Kolbe), J Agric Food Chem., 57(15), pp.6596-602, 2009.

[10] Feng, T., Xu, Y., Cai, X.H., Du, Z.Z. \& Luo, X.D., Antimicrobially Active Isoquinoline Alkaloids from Litsea cubeba, Planta Med., 75(1), pp. 76-9. 2009.

[11] Luo, M., Jiang, L.K. \& Zou, G.L., Acute and Genetic Toxicity of Essential Oil Extracted from Litsea cubeba (Lour.) Pers. J Food Prot., 68(3), pp.581-8, 2005.

[12] Wang, H. \& Liu, Y., Chemical Composition and Antibacterial Activity of Essential Oils from Different Parts of Litsea cubeba, Chem Biodivers., 7(1), pp. 229-35, 2010.

[13] Hwang, J.K., Choi, E.M. \& Lee, J.H., Antioxidant Activity of Litsea cubeba, Fitoterapia, 76(7-8), pp. 684-6, 2005.

[14] Silamba, I., The Aromatic Profile Identification of Two Pineapple Varieties and its Offspring Using Gas Chromatography-Mass Spectrometer and Gas Chromatography-olfactometry with the Censor Quality Test, Master Degree Thesis, Institut Pertanian Bogor, Bogor, 2011. (Text in Indonesian)

[15] Ali, C. \& Manik, S., The Prospect of Litsea cubeba Cultivation Development in North Sumatera, in Proceeding of Research Results, Aek Nauli Forestry Research Center, ed., Medan, 3 December 2008. (Text in Indonesian)

[16] Si, L., Chen,Y., Han, X. J., Zhan, Z., Tian, S., Cui, Q. \& Wang, Y., Chemical Composition of Essential Oils of Litsea cubeba Harvested from its Distribution Areas in China, Molecules, 17, pp. 7057-7066 2012. (Text in Indonesian)

[17] Cesco, S., Mimmo, T., Tonon, G., Tomasi, N., Pinton, R., Terzano, R., Neumann, G., Weisskopf, L., Renella, G. \& Landi, L., Plant-borne Flavonoids Released into the Rhizosphere: Impact on Soil Bio-Activities Related to Plant Nutrition, A Review, Biology and Fertility of Soils, 48(2), pp. 123-149, 2007.

[18] Ubonnuch, C., Chemical Composition and Antimicrobial Activity of Essential Oil of Litsea cubeba Leaves and Litsea Glutinosa Fruits, Chulalongkorn Univ., Faculty of Pharmaceutical, 2005.

[19] Zhao, O., Zhou, J.W. \& Ban, D.M., Analysis of Volatile Oil from Different Parts of Litsea cubeba, Zhong Yao Cai., 33(9), pp. 1417-9, 2010. (Text in Chinese) 